\title{
EKSPERIMENTASI MODEL PEMBELAJARAN MISSOURI MATHEMATICS PROJECT (MMP) TERMODIFIKASI DITINJAU DARI KEMAMPUAN SPASIAL SISWA KELAS X SMA NEGERI KOTA SURAKARTA
}

\begin{abstract}
Santosa
Abstract

This research is aimed: (1) To know which model among the MMP modified model, MMP model and the conventional model that produces a better student achievement. (2). To know which students who have better learning achievement among those who have high spatial ability, medium and low. (3). To know which model that produces better student achievement, the MMP modified modeI, MMP model or conventional model at each level of students's spatial abilities.

This is a quasi-experimental research design with a factorial $3 \times 3$. The research population is students of Grade X Senior High School Students Surakarta of the academic year 2010/2011. The sampling technique is a combination of studies stratified random sampling and cluster random sampling. The selected samples of this research are: (1). First experimental group consist of 99 student's (34 students of X1 class of SMA Negeri 2 Surakarta, 33 students of X1 class of SMA Negeri 3 Surakarta and 32 students of X5 class of SMA Negeri 8 Surakarta; (2). Second experimental group consist of 100 student's (34 students of X2 class of SMA Negeri 2 Surakarta, 34 students of X2 class of SMA Negeri 3 Surakarta and 32 students of X6 class of SMA Negeri 8 Surakarta; (3). Control group consist of 100 student's (34 students of X3 class of SMA Negeri 2 Surakarta, 34 students of X3 class of SMA Negeri 3 Surakarta and 32 students of X7 class of SMA Negeri 8 Surakarta.

The instrument used for data collection is the preliminary ability tests, achievement tests and ability tests of spatial learning of students in the form of multiple choice. Before the test instruments are used, they are being tried out first. For preliminary ability and achievement test, the validity, reliability (used KR-20 test) and difference and difficulty level tests are tried out. While the instruments of spatial ability tests are taken from standardized tests so they do not need any try out. Before conducting the research first tested using a one-way Analysis of Variants with an unequal cell. Hypothesis of the research were tested by using a two-way Analysis of Variants with an unequal cell at the significance level of 5\%. Previously, it is prerequisites tested, namely: normality test using the test Lilliefors and homogeneity test using Bartlett's test.

The conclusion of this research are: (1) The MMP modified learning model produce student achievement better than the MMP learning model and the conventional learning model, and the MMP learning model produces a better student achievement than conventional model; (2) The students who have high spatial ability are having better academic achievement than students who have medium and low spatial abilities, and students who have medium spatial abilities are having better academic achievement than students of low spatial ability; (3) On the students who have high spatial ability, the MMP modified learning model, the MMP learning model and conventional learning model produce similar student achievement. While the students who have medium and low spatial ability, the MMP learning modified model produce student achievement better than the MMP learning model and conventional learning model, and the MMP learning model produces student achievement better than the conventional learning model.
\end{abstract}

Keywords: Learning Model, Missouri Mathematics Project, Spatial Ability.

PENDAHULUAN
Perubahan dan perkembangan zaman

semakin menuntut semua disiplin ilmu untuk 
bisa diterapkan dalam kehidupan nyata, tidak terkecuali dengan matematika. Oleh karena itu, diperlukan suatu sistem yang dapat menghasilkan lulusan yang mampu berkompetisi dan dapat berperan dalam menerapkan matematika untuk memecahkan masalah sehari-hari.

Penerapan dan pengembangan matematika dalam kehidupan sehari-hari tidak akan mungkin terjadi jika siswa tidak memahami dan terampil dalam menyelesaikan masalah. Hal inilah yang saat ini terjadi dalam dunia pendidikan di Indonesia pada umumnya, setidaknya jika nilai Ujian Nasional (UN) dijadikan sebagai sebuah indikator. Jika memperhatikan nilai rata-rata ujian nasional mata pelajaran matematika mulai tahun pelajaran 2007/2008 sampai dengan 2009/2010 masih di bawah 7,50 kecuali untuk tingkat nasional pada tahun ajaran 2009/2010. Jika dibandingkan dengan kondisi sekarang, dimana banyak sekolah yang berlomba untuk menuju sekolah bertaraf internasional, maka nilai 7,50 sama dengan nilai ketuntasan minimal bagi sekolah bertaraf internasional. Hal ini berarti nilai 7,50 adalah nilai yang tergolong rendah. Bertolak dari hal ini, tentu sangat diperlukan adanya upaya serius agar nilai matematika siswa dapat ditingkatkan.

Upaya untuk meningkatkan kualitas pendidikan di Indonesia telah banyak dilakukan oleh berbagai pihak. Salah satu upaya yang dilakukan diantaranya adalah pemilihan model pembelajaran yang tepat dalam menyajikan materi pembelajaran kepada siswa yang karakteristiknya beraneka ragam. Beberapa guru masih menggunakan model pembelajaran yang sama untuk kelas yang berbeda dan untuk materi yang berbeda-beda pula. Meskipun masih dalam sekolah yang sama, siswa pada dua kelas yang berbeda boleh jadi memiliki karakteristik yang berbeda pula. Akibatnya, penerapan model yang sama untuk kedua kelas tersebut boleh jadi merupakan suatu langkah yang kurang tepat.

Model Missouri Mathematics Project (MMP) adalah model pembelajaran yang terstruktur seperti halnya SPM (Struktur Pembelajaran Matematika), tetapi MMP mengalami pengembangan dengan lima langkah yang tersruktur dengan baik. Kelima langkah dalam MMP tersebut meliputi: (1) Review, (2) Pengembangan, (3) Latihan terkontrol, (4). Seatwork dan (5) PR. Model ini memiliki banyak kelebihan, diantaranya banyak materi yang dapat disampaikan kepada siswa. Di samping kelebihannya, model MMP juga memiliki kekurangan. Kekurangan tersebut antara lain siswa ditempatkan pada posisi yang kurang aktif, mereka lebih banyak mendengar. Jika hal ini terus terjadi, dikhawatirkan terdapat siswa yang akan mengalami kebosanan dalam mengikuti pelajaran.

Model pembelajaran TAI (Team Assisted Individualization) termasuk dalam model pembelajaran kooperatif. Dengan model pembelajaran kooperatif tipe TAI diharapkan siswa dapat benar-benar aktif 
dalam proses pembelajaran, sehingga diharapkan dapat meningkatkan prestasi belajar matematika siswa. Kelemahan dari model ini adalah relatif membutuhkan waktu yang lebih lama untuk mempelajari suatu materi.

Menyadari kelebihan dan kekurangan dari setiap model pembelajaran, maka menggabungkan atau memodifikasi suatu model merupakan suatu upaya yang mungkin dapat dilakukan. Sebagai contoh guru dapat menggunakan model kooperatif TAI pada langkah kerja kooperatif ketika menggunakan model MMP dalam pembelajaran. Kemudian pada model TAI tersebut siswa dipersilakan menggunakan media komputer untuk mempermudah memahami konsep. Dengan model dan bantuan media seperti ini, kemungkinan kelemahan masing-masing model dapat tertutupi. Akibatnya proses belajar mengajar diharapkan dapat berjalan dengan baik dan efektif sehingga tujuan pembelajaran dapat dicapai.

Geometri merupakan salah satu materi dalam mata pelajaran matematika SMA yang selama ini dianggap sulit bagi kebanyakan siswa. Rendahnya prestasi siswa pada materi geometri kemungkinan disebabkan oleh lemahnya kemampuan siswa memvisualisasikan obyek-obyek geometri dalam bentuk yang lebih nyata. Beberapa guru sudah berusaha mengatasi hal ini, mulai dari memberikan contoh ruangan kelas sampai membuat model-model geometri yang sesuai. Akan tetapi, tidak semua contoh dan model tersebut mampu memvisualisasikan obyek yang dimaksud dengan baik.

Memahami sebuah konsep adalah suatu proses. Dalam tahap awal, tentu tidak menjadi masalah jika siswa harus dibantu dalam memvisualisasikan bentuk-bentuk geometri tersebut dengan bantuan media, seperti pemanfaatan software komputer untuk pembelajaran.

Dalam mempelajari materi geometri faktor intelegensi memegang peranan penting. Salah satu elemen dalam intelegensi adalah kemampuan spasial. Kemampuan spasial berkaitan dengan kemampuan untuk menggambarkan bentuk dari berbagai benda, bagaimana dimensi, koordinat, proporsi, pergerakan dan tekstur fisik dari benda.

Berdasarkan identifikasi masalah yang disampaikan, maka dirumuskan permasalahan penelitian ini adalah sebagai berikut: (1) Di antara model MMP termodifikasi, model MMP dan model konvensional, model manakah yang menghasilkan prestasi belajar siswa yang lebih baik?. (2) Di antara siswa yang mempunyai kemampuan spasial tinggi, sedang dan rendah, siswa manakah yang mempunyai prestasi belajar lebih baik?. (3) Pada masing-masing tingkat kemampuan spasial siswa, model manakah yang menghasilkan prestasi belajar siswa yang lebih baik, model MMP termodifikasi, model MMP atau model konvensional?

\section{METODE PENELITIAN}


Penelitian ini merupakan penelitian eksperimental semu dengan desain faktorial $3 \times 3$. Populasi penelitian adalah siswa SMA Negeri Kota Surakarta kelas $\mathrm{X}$ tahun pelajaran 2010/2011. Teknik pengambilan sampel penelitian adalah kombinasi dari sampling random stratifikasi (stratified random sampling) dan sampling random kluster (cluster random sampling). Sampel terpilih dalam penelitian ini adalah: (1). Kelompok eksperimen 1 terdiri dari 99 siswa (34 siswa kelas X1 SMA Negeri 2 Surakarta, 33 siswa kelas X1 SMA Negeri 3 Surakarta dan 32 siswa Kelas X5 SMA Negeri 8 Surakarta); (2). Kelompok eksperimen 2 terdiri dari 100 siswa (34 siswa kelas X2 SMA Negeri 2 Surakarta, 34 siswa kelas X2 SMA Negeri 3 Surakarta dan 32 siswa kelas X6 SMA Negeri 8 Surakarta); (3). Kelompok kontrol teridiri dari 100 siswa (34 siswa kelas X3 SMA Negeri 2 Surakarta, 34 siswa kelas X3 SMA Negeri 3 Surakarta dan 32 siswa kelas X7 SMA Negeri 8 Surakarta). Pengujian hipotesis menggunakan Anava dua jalan dengan sel tak sama, dengan taraf signifikan $5 \%$. Sebelumnya dilakukan uji prasyarat yaitu: uji normalitas menggunakan uji Liliefors dan uji homogenitas menggunakan uji Bartlett.

\section{HASIL PENELITIAN}

Hipotesis dalam penelitian ini adalah: (1) Model pembelajaran MMP termodifikasi menghasilkan prestasi belajar siswa yang lebih baik daripada model pembelajaran MMP dan model pembelajaran konvensional, dan model pembelajaran MMP menghasilkan prestasi belajar siswa yang lebih baik daripada model pembelajaran konvensional. (2) Siswa yang mempunyai kemampuan spasial tinggi lebih baik prestasi belajarnya daripada siswa yang kemampuan spasialnya sedang dan rendah, dan siswa yang mempunyai kemampuan spasial sedang lebih baik prestasi belajarnya daripada siswa yang kemampuan spasialnya rendah. (3) Pada masing-masing tingkat kemampuan spasial siswa, model pembelajaran MMP termodifikasi menghasilkan prestasi belajar siswa yang lebih baik daripada model pembelajaran MMP dan model pembelajaran konvensional, sedangkan model pembelajaran MMP menghasilkan prestasi belajar siswa yang lebih baik daripada model pembelajaran konvensional.

Pengujian hipotesis dilakukan dengan menggunakan teknik analisis variansi dua jalan dengan tidak sama dan hasilnya disajikan pada Tabel 1.

Tabel 1 Rangkuman Analisis Variansi

\begin{tabular}{|l|l|l|l|l|l|l|}
\hline \multicolumn{1}{|c|}{ Sumber } & \multicolumn{1}{c|}{ JK } & \multicolumn{1}{c|}{ Dk } & \multicolumn{1}{c|}{ RK } & \multicolumn{1}{|c|}{ F $_{\text {obs }}$} & $\mathbf{F}_{\text {kritik }}$ & $\begin{array}{c}\text { Keputusan } \\
\text { uji }\end{array}$ \\
\hline Model pembelajaran (A) & 4673,4193 & 2 & 2336,7096 & 52,6271 & 3,00 & Ditolak \\
\hline Kemampuan Spasial (B) & 14032,0133 & 2 & 7016,0066 & 158,0138 & 3,00 & Ditolak \\
\hline Interaksi (AB) & 1092,8152 & 4 & 273,2038 & 6,1531 & 2,37 & Ditolak \\
\hline Galat (G) & 12876,3568 & 290 & 44,401 & - & - & - \\
\hline Total & 32674,6045 & 298 & - & - & - & - \\
\hline
\end{tabular}


Tabel 4.12 Rangkuman Rerata antar Sel dan Rerata Marginal

\begin{tabular}{|lc|l|l|l|l|}
\hline \multicolumn{2}{|c|}{ Model } & \multicolumn{4}{c|}{ Kemampuan Spasial } \\
\cline { 3 - 6 } & & \multicolumn{1}{|c|}{ Tinggi $\left(\mathbf{B}_{\mathbf{1}}\right)$} & Sedang $\left(\mathbf{B}_{2}\right)$ & Rendah $\left(\mathbf{B}_{3}\right)$ & Rerata Marginal \\
\hline MMP T & $\left(\mathrm{a}_{1}\right)$ & 79,7500 & 75,4118 & 67,2727 & 74,1010 \\
\hline MMP & $\left(\mathrm{a}_{2}\right)$ & 76,6250 & 69,2632 & 60,9333 & 69,1200 \\
\hline Konvensional & $\left(\mathrm{a}_{3}\right)$ & 76,5333 & 62,6341 & 54,0690 & 64,3200 \\
\hline Rerata Marginal & 77,6596 & 68,7080 & 61,0435 & \\
\hline
\end{tabular}

Tabel 4.13 Rangkuman Keputusan Uji Komparasi Ganda

\begin{tabular}{|c|c|c|c|c|}
\hline Jenis Komparasi & Komparasi & $\mathbf{F}_{\text {obs }}$ & $\mathbf{F}_{\text {kritik }}$ & Keputusan uji \\
\hline \multirow[t]{3}{*}{ Antar baris } & $\mu_{1 .}$ vs $\mu_{2}$ & 27,7985 & 6 & $\mathrm{H}_{0}$ ditolak \\
\hline & $\mu_{1 .}$ vs $\mu_{3}$ & 107,1901 & 6 & $\mathrm{H}_{0}$ ditolak \\
\hline & $\mu_{2 .} \mathrm{vs} \mu_{3}$ & 25,9452 & 6 & $\mathrm{H}_{0}$ ditolak \\
\hline \multirow[t]{3}{*}{ Antar kolom } & $\mu_{.1}$ vs $\mu_{.2}$ & 92,6069 & 6 & $\mathrm{H}_{0}$ ditolak \\
\hline & $\mu_{.1}$ vs $\mu_{.3}$ & 289,1117 & 6 & $\mathrm{H}_{0}$ ditolak \\
\hline & $\mu .2$ vs $\mu .3$ & 67,094 & 6 & $\mathrm{H}_{0}$ ditolak \\
\hline \multirow{9}{*}{$\begin{array}{l}\text { Antar sel pada kolom } \\
\text { yang sama }\end{array}$} & $\mu_{11}$ vs $\mu_{21}$ & 3,519 & 15,52 & $\mathrm{H}_{0}$ diterima \\
\hline & $\mu_{11}$ vs $\mu_{31}$ & 3,6083 & 15,52 & $\mathrm{H}_{0}$ diterima \\
\hline & $\mu_{21}$ vs $\mu_{31}$ & 0,0029 & 15,52 & $\mathrm{H}_{0}$ diterima \\
\hline & $\mu_{12}$ vs $\mu_{22}$ & 15,8256 & 15,52 & $\mathrm{H}_{0}$ ditolak \\
\hline & $\mu_{12}$ vs $\mu_{32}$ & 56,9357 & 15,52 & $\mathrm{H}_{0}$ ditolak \\
\hline & $\mu_{22}$ vs $\mu_{32}$ & 15,8352 & 15,52 & $\mathrm{H}_{0}$ ditolak \\
\hline & $\mu_{13}$ vs $\mu_{23}$ & 16,2417 & 15,52 & $\mathrm{H}_{0}$ ditolak \\
\hline & $\mu_{13}$ vs $\mu_{33}$ & 60,7967 & 15,52 & $\mathrm{H}_{0}$ ditolak \\
\hline & $\mu_{23}$ vs $\mu_{33}$ & 16,4318 & 15,52 & $\mathrm{H}_{0}$ ditolak \\
\hline
\end{tabular}

\section{PEMBAHASAN HASIL PENELITIAN}

\section{Hipotesis Pertama}

Hipotesis pertama dalam penelitian ini adalah "Model pembelajaran MMP termodifikasi menghasilkan prestasi belajar siswa yang lebih baik daripada model pembelajaran MMP dan model pembelajaran konvensional, dan model pembelajaran MMP menghasilkan prestasi belajar siswa yang lebih baik daripada model pembelajaran konvensional". Berdasarkan hasil analisis variansi dua jalan dengan sel tak sama untuk efek utama faktor A (model pembelajaran) diperoleh nilai statistik uji $\mathrm{F}_{\text {obs }}=52,6271$. Karena $\mathrm{F}_{\text {kritik }}=3,00$, maka $\mathrm{F}_{\text {obs }}>\mathrm{F}_{\text {kritik. }}$. Dengan demikian $\mathrm{H}_{0 \mathrm{~A}}$ ditolak. Hal ini berarti pada tingkat signifikansi $\quad \alpha=0,05$ model pembelajaran MMP termodifikasi, model pembelajaran MMP dan model pembelajaran konvensional menghasilkan prestasi belajar siswa yang tidak sama.

Dari uji komparasi ganda antar baris diperoleh hasil bahwa model pembelajaran MMP termodifikasi menghasilkan prestasi belajar siswa yang lebih baik daripada model pembelajaran MMP dan model konvensional, sedangkan model pembelajaran MMP menghasilkan prestasi belajar siswa yang lebih baik 
daripada model pembelajaran konvensional.

\section{Hipotesis Kedua}

Hipotesis kedua dalam penelitian ini mengatakan bahwa "Siswa yang mempunyai kemampuan spasial tinggi lebih baik prestasi belajarnya daripada siswa yang kemampuan spasialnya sedang dan rendah, dan siswa yang mempunyai kemampuan spasial sedang lebih baik prestasi belajarnya daripada siswa yang kemampuan spasialnya rendah”. Berdasarkan hasil analisis variansi dua jalan dengan sel tak sama untuk efek utama faktor B (kemampuan spasial siswa) diperoleh harga statistik uji $F_{\text {obs }}=158,0138$. Karena $F_{\text {kritik }}=3,00$, maka $\mathrm{F}_{\text {obs }}>\mathrm{F}_{\text {kritik. }}$. Dengan demikian $\mathrm{H}_{0 \mathrm{~B}}$ ditolak. Hal ini berarti pada tingkat signifikansi $\quad \alpha=0,05 \quad$ terdapat perbedaan prestasi belajar antara siswa yang berkemampuan spasial tinggi, sedang dan rendah.

Dari uji komparasi ganda antar kolom diperoleh hasil bahwa siswa yang mempunyai kemampuan spasial tinggi lebih baik prestasi belajarnya daripada siswa yang kemampuan spasialnya sedang dan rendah, sedangkan siswa yang mempunyai kemampuan spasial sedang lebih baik prestasi belajarnya daripada siswa yang kemampuan spasialnya rendah.

\section{Hipotesis Ketiga}

Hipotesis ketiga dalam penelitian ini mengatakan bahwa "Pada masing- masing tingkat kemampuan spasial siswa, model pembelajaran MMP termodifikasi menghasilkan prestasi belajar siswa yang lebih baik daripada model pembelajaran MMP dan model pembelajaran konvensional, sedangkan model pembelajaran MMP menghasilkan prestasi belajar siswa yang lebih baik daripada model pembelajaran konvensional”. Berdasarkan hasil analisis variansi dua jalan dengan sel tak sama untuk efek AB (interaksi) diperoleh nilai statistik uji $F_{\text {obs }}=6,1531$. Karena $F_{\text {kritik }}=2,37$, maka $\mathrm{F}_{\text {obs }}>\mathrm{F}_{\text {kritik }}$. Dengan demikian $\mathrm{H}_{0 \mathrm{AB}}$ ditolak. Hal ini berarti pada tingkat signifikansi $\alpha=0,05$ terdapat interaksi antara model pembelajaran dan kemampuan spasia siswa terhadap prestasi belajar siswa. Karena $\mathrm{H}_{0}$ ditolak, maka perlu dilakukan uji komparasi ganda antar sel pada kolom yang sama.

a. Komparasi ganda antar sel pada kolom pertama

Dari uji komparasi ganda antar sel pada kolom pertama diperoleh hasil bahwa pada siswa yang berkemampuan spasial tinggi model pembelajaran MMP termodifikasi, model pembelajaran MMP dan model pembelajaran konvensional menghasilkan prestasi belajar siswa yang sama baiknya..

b. Komparasi ganda antar sel pada kolom kedua. 
Dari uji komparasi ganda antar sel pada kolom ke dua diperoleh hasil bahwa pada siswa yang berkemampuan sedang, model MMP termodifikasi menghasilkan prestasi belajar siswa yang lebih baik daripada model MMP dan model konvensional, sedangkan model MMP menghasilkan prestasi belajar siswa yang lebih baik daripada model konvensional.

c. Komparasi ganda antar sel pada kolom ketiga

Dari uji komparasi ganda antar sel pada kolom ke tiga diperoleh hasil bahwa pada siswa yang berkemampuan rendah, model MMP termodifikasi menghasilkan prestasi belajar siswa yang lebih baik daripada model MMP dan model konvensional, sedangkan model MMP menghasilkan prestasi belajar siswa yang lebih baik daripada model konvensional.

\section{KESIMPULAN}

Berdasarkan analisa data dan pembahasan, dapat disimpulkan beberapa hal sebagai berikut:

1. Model MMP termodifikasi menghasilkan prestasi belajar siswa yang lebih baik daripada model MMP dan model konvensional, dan model MMP menghasilkan prestasi belajar siswa yang lebih baik daripada model konvensional.
2. Siswa yang mempunyai kemampuan spasial tinggi lebih baik prestasi belajarnya daripada siswa yang kemampuan spasialnya sedang dan rendah, dan siswa yang mempunyai kemampuan spasial sedang lebih baik prestasi belajarnya daripada siswa yang kemampuan spasialnya rendah.

3. Pada siswa yang berkemampuan spasial tinggi, model MMP termodifikasi, model MMP dan model konvensional menghasilkan prestasi belajar siswa yang sama baik. Sedangkan pada siswa yang berkemampuan spasial sedang dan rendah, model MMP termodifikasi menghasilkan prestasi belajar siswa yang lebih baik daripada model MMP dan model konvensional, dan model MMP menghasilkan prestasi belajar siswa yang lebih baik daripada model konvensional.

\section{SARAN}

1. Kepada guru mata pelajaran matematika

a. Guru mencoba mengatasi kelemahan proses pembelajaran telah terjadi dalam menerapkan model pembelajaran MMP termodifikasi.

b. Guru hendaknya lebih inovatif dan bersedia belajar menggunakan software-software pembelajaran yang dapat digunakan dalam proses pembelajaran di kelas.

c. Guru dalam proses pembelajaran hendaknya lebih banyak melibatkan siswa, guru tidak mendominasi seluruh proses pembelajaran. 
d. Dalam memilih model pembelajaran hendaknya guru memperhatikan perbedaan karakteristik siswa yang unik, salah satunya adalah perbedaan kemampuan spasial siswa.

2. Kepada Pemegang Kebijakan dalam Pendidikan

Pemegang kebijakan di sekolah hendaknya menyediakan sarana dan prasarana yang menunjang proses pembelajaran, misalnya menyediakan buku-buku dan komputer yang memadai sehingga proses pembelajaran dapat dilakukan dengan lebih inovatif dan lebih menarik.

3. Saran bagi para peneliti/calon peneliti

Peneliti/calon peneliti diharapkan dapat mengembangkan hasil penelitian ini pada lingkup yang lebih luas, misalnya perbedaan prestasi belajar siswa jika ditinjau dari prestasi belajar TIK mereka. Selain itu peneliti/calon peneliti dapat meneruskan atau mengembangkan penelitian ini untuk variabel-variabel lain yang sejenis, misalnya modifikasi dengan model kooperatif lain atau penggunaan software-software lain dalam proses pembelajaran, sehingga dapat memberikan wawasan baru dalam dunia pendidikan khususnya dalam pembelajaran matematika.

\section{DAFTAR PUSTAKA}

Ali Akbar, 2006. Panduan Cepat Menguasai Teknologi Informasi dan Komunikasi. Yogyakarta: Gava Media
Anita Lie. 2008. Cooperative Learning. Jakarta: Grasindo.

Arief S. Sadiman, dkk. 1996. Media Pendidikan (Pengertian, Pengembangan dan Pemanfaatannya), Jakarta: PT. Raja Grafindo Persada.

Austin. 2007. Interactive Learning in Mathematics Education. The Journal of Computers in Mathematics and Science Teaching. 26 (2). 137 - 154.

Budiyono. 2003. Metodologi Penelitian Pendidikan. Surakarta: Sebelas Maret University Press.

Budiyono. 2009. Statistika untuk Penelitian. Edisi Ke-2. Surakarta: UNS Press.

Campbel, Linda. 2002. Multiple Intelegences. Jakarta: Inisiasi Pers.

Duren, Phillip E. 1992. The Effects of Cooperative Group Work Versus Independent Practice on the Learning of Some Problem Solving Strategies. ProQuest Education Journal. 92(2). 80 $-83$.

Dwi Sunar Prasetyono. 2010. Ensiklopedi Soal-soal Psikotes Khusus Gambar, Angka dan Matematika. Yogyakarta: Flash Book.

Gergelitsová, Š. 2007. Computer Aided Development of Spatial Abilities. WDS'07 Proceedings of Contributed Papers, Part I, 246-250, 2007.

Isjoni.2009. Pembelajaran Kooperatif. Yogyakarta: Pustaka Pelajar.

JL Pasaribu \& B.Simanjuntak. 1982. Sosiologi Pendidikan. Bandung: Tarsito.

John, D. Latuheru. 1988. Media Pembelajaran dalam Proses BelajarMengajar Masa Kini. Jakarta: Depdikbud.

Kamus Besar Bahasa Indonesia. 2002. Jakarta. Depdiknas. 
M.G. Erni Harmiati. 2008. Peningkatan Motivasi belajar dan Pemahaman Keruangan Siswa Melalui Pembelajaran Geometri Berbantuan Komputer. Surakarta: Univeritas Sebelas Maret.

Mehrens, William A dan Lehmann, Irvin J. 1972. Measurement and Evaluation in Education and Psychology. New York: Holt, Rinehart and Winston, Inc.

Meixia Ding, Xiaobao Li, Diana Piccolo, Gerald Kulm. 2007. Teacher Interventions in Cooperative-Learning Mathematics Classes. The Journal of Educational Research. Bloomington. Vol. 100/3; $162-177$.

Muhamad Nur dan Prima Retno Wikandari. 2000. Pengajaran Berpusat kepada siswa dan Pendekatan kontruktivis Dalam Pengajaran. Surabaya: UNESA University Press.

Nana Sudjana.1995. Penilaian Hasil Proses Belajar Mengajar. Bandung: Remaja Rosda Karya.

Sadiman, A.S. Dkk. 2003. Media Pendidikan Pengertian, Pengembangan dan Pemanfaatannya. Jakarta: Penerbit PT Raja Grafindo Persada.

Saifuddin Azwar. 1999. Pengantar Psikologi Intelegensi. Yogyakarta: Pustaka Pelajar.

Siti Marliah Tambunan. 2006. Hubungan antara Kemampuan Spasial dengan Prestasi Belajar Matematika. Jurnal Makara, Sosial Humaniora Vol 10, No.1, Juni 2006.

Slavin Robert E. 2005. Cooperative Learning. Bandung: Nusa Media.
Slavin Robert E. 1997. Cooperative Learning: Theory, Research, and Practice. Massachusets: Allyn and Bacon Publishers.

Slavin Robert. 2010. Cooperative Learning. Teori, Riset dan Praktik. Bandung: Nusa Media.

Soedjadi R. 2000. Kiat Pendidikan Matematika di Indonesia. Jakarta: Dirjen Penduidikan Tinggi Depdiknas.

Suharsimi Arikunto. 2002. Prosedur Penelitian Suatu Pendekatan Praktek. Jakarta: Rineka Cipta.

Sutratinah Tirtonegoro. 2001. Anak Supernormal Dan Program Pendidikannya. Jakarta: PT. Bumi Aksara.

Suwantarathip, Wichadee. 2010. The Impact of Cooperative learning on axiety and proficiency in an EFL class. Journal Wo.PaLP. Vol. 3, p.30-34.

Tapan Kumar Tiwari. 2007. Computer Graphics as an Instructional Aid in an Introductory Diferential Calculus Course. International Electronic Journal of Mathematics Education. Vol. 2. N.1, p.32-48.

Yu-Fen Chen, Kai-When Cheng. 2009 Integrating computer-supported cooperative learning and creative problem solving in to a single teaching strategy. Journal of Education Technology. Volume 3, n 1, p $30-45$. 